\title{
SOIL TILLAGE, WATER EROSION, AND CALCIUM, MAGNESIUM AND ORGANIC CARBON LOSSES
}

\author{
Ildegardis Bertol ${ }^{1 *}$; Jean Cláudio Guadagnin ${ }^{1}$; Antonio Paz González ${ }^{2}$; André Júlio do Amaral ${ }^{1}$; \\ Leonardo Felipe Brignoni ${ }^{1}$ \\ ${ }^{1}$ UDESC/CAV - Depto. de Solos, C.P. 281 - 88520-000 - Lages, SC - Brasil. \\ ${ }^{2} U D C$ - Depto. de Ciencias de la Tierra y de la Navegación, C.P. 15071 - Coruña, España. \\ *Corresponding author <a2ib@cav.udesc.br>
}

\begin{abstract}
Soil tillage influences water erosion, and consequently, losses of calcium, magnesium and organic carbon in surface runoff. Nutrients and organic carbon are transported by surface runoff in particulate form, adsorbed to soil colloids or soluble in water, depending on the soil tillage system. This study was carried out on an Inceptisol, representative of the Santa Catarina highlands, southern Brazil, between November 1999 and October 2001, under natural rainfall. The soil tillage treatments (no replications) were: no-tillage (NT), minimum soil tillage with chiseling + disking (MT), and conventional soil tillage with plowing + two diskings (CT). The crop cycles sequence was soybean (Glycine max), oats (Avena sativa), beans (Phaseolus vulgaris) and vetch (Vicia sativa). Conventional soil tillage treatment with plowing + two disking in the absence of crops (BS) was also studied. Calcium and magnesium concentrations were determined in both water and sediments of the surface runoff, while organic carbon was measured only in sediments. Calcium and magnesium concentrations were greater in sediments than in surface runoff, while total losses of these elements were greater in surface runoff than in sediments. The greatest calcium and magnesium concentrations in surface runoff were obtained under CT, while in sediments the greatest concentration occurred under MT. Organic carbon concentration in sediments did not differ under the different soil tillage systems, and the greatest total loss was under CT system.
\end{abstract}

Key words: runoff, sediment, nutrient in runoff, nutrient in sediments, nutrient losses

\section{PREPARO DO SOLO, EROSÃO HÍDRICA, E PERDAS DE CÁLCIO, MAGNÉSIO E CARBONO ORGÂNICO}

\begin{abstract}
RESUMO: O preparo do solo influencia a erosão hídrica e, consequentemente, as perdas de cálcio, magnésio e carbono orgânico. Nutrientes e carbono orgânico são transportados na enxurrada superficial, podendo estar predominantemente adsorvidos aos colóides do solo ou solúveis na água, dependendo do sistema de preparo do solo. Este trabalho foi conduzido em um Inceptisol, representativo das terras de altitude de Santa Catarina, sul do Brasil, entre novembro de 1999 e outubro de 2001, sob chuva natural. Os tratamentos de preparo do solo, sem repetição, foram: semeadura direta (SD), preparo mínimo do solo com escarificação + gradagem (PM) e preparo convencional do solo com aração + duas gradagens (PC), com a seqüência dos cultivos de soja (Glycine max), aveia preta (Avena sativa), feijão (Phaseolus vulgaris) e ervilhaca comum (Vicia sativa). Um tratamento de preparo convenvional do solo com aração + duas gradagens na ausência de cultivo (SC) foi também estudado. Os conteúdos de cálcio e magnésio foram determinados na água e nos sedimentos da enxurrada superficial, enquanto o de carbono orgânico foi avaliado somente nos sedimentos. As concentrações de cálcio e magnésio foram maiores nos sedimentos do que na água da enxurrada superficial, enquanto as perdas totais desses elementos foram maiores na água do que nos sedimentos. As maiores concentrações de cálcio e magnésio na água da enxurrada superficial foram observadas sob PC, enquanto nos sedimentos as maiores concentrações ocorreram sob PM. A concentração de carbono orgânico nos sedimentos não diferiu nos tratamentos de preparo do solo, contudo, as perdas totais foram maiores sob PC.

Palavras-chave: enxurrada, sedimentos, nutrientes na enxurrada, nutrientes nos sedimentos, perdas de nutrientes
\end{abstract}

\section{INTRODUCTION}

No-tillage system is efficient in reducing soil losses caused by rainfall erosion, when compared to the conventional tillage (Cogo, 1981; Bertol, 1995). However, these effects are generally lower on water, and chemical and organic elements losses (Schick et al., 2000; Bertol et al., 2003).

The no-tillage system produces lower water and sediments losses by rainfall erosion than conventional tillage (Cogo, 1981; Bertol, 1995), while runoff of conventional tillage usually concentrates less plant nutrients and 
organic carbon (Pote et al., 1996; Favaretto, 2002). In the case of calcium and magnesium, their contents in runoff deriving from a no-tillage system are similar or lower than in runoff deriving from conventional tillage (Schick et al., 2000).

The marked accumulation of mineral and organic nutrients in the superficial soil layer in no-tillage, in comparison to the conventional tillage (Eltz et al., 1989; Schick et al., 2000), is responsible for high concentrations of some elements in runoff from no-tilled areas (Bertol et al., 2003). Hernani et al. (1999) found greater calcium and magnesium concentrations in runoff water from no-tillage than from conventional tillage, while Schick et al. (2000) did not show a clear trend related to any of these two referred soil tillage systems. Bertol et al. (2003) also found greater calcium and magnesium concentrations in runoff water from a conventional tillage than from a no-tillage. On the other hand, finding higher calcium, magnesium and organic carbon concentrations in sediments than in water from erosion is a common trend (Hernani et al., 1999: Schick et al., 2000; Bertol et al., 2003; Guadagnin, 2003). Moreover, sometimes calcium and magnesium concentrations are higher in runoff sediments than in superficial soil layer (Stoltenberg \& White, 1953); in other conditions an inverse behavior would be observed (Schick et al., 2000).

The objective of this study was to determine concentrations and calculate total losses of calcium and magnesium in both surface runoff water and sediment, and organic carbon in surface runoff sediment only, on an Inceptisol under different soil tillage systems.

\section{MATERIAL AND METHODS}

The experiment was carried out from November 1999 to October 2001, in Santa Catarina State highlands, southern Brazil $\left(27^{\circ} 49^{\prime} \mathrm{S}, 50^{\circ} 20^{\prime} \mathrm{W}\right.$; altitude $\left.937 \mathrm{~m}\right)$. The area's climate is subtropical $\mathrm{Cfb}$ type, according to the Köppen classification, with average annual precipitation of $1,600 \mathrm{~mm}$. The soil at the experimental area is a loamy Inceptisol, average slope of $0.102 \mathrm{~m} \mathrm{~m}^{-1}$, (Bertol, 1994). This experimental area has been used for studies of water erosion under natural rainfall since November 1988.

The experimental area consisted of plots with $22.1 \mathrm{~m} \times 3.5 \mathrm{~m}$, delimited in the upper and lateral extremities by galvanized sheets inserted $0.1 \mathrm{~m}$ into the soil, and in the lower extremity, by a runoff collector system (gutter). The gutter was connecting by a plastic tube to the first tank, distant $6 \mathrm{~m}$ from the plot. The first tank was connected to the second tank through a runoff divisor, "Geib" type, with nine windows.

The soil tillage systems were randomly distributed without replication, as follows: a) conventional soil tillage with plowing + two disking $(\mathrm{CT})$; b) minimum soil tillage with chiseling + disking (MT); c) no-tillage (NT), with either, soybean, oats, bean, or vetch crops. A treatment of conventional soil tillage, with plowing + two disking without soil crop (BS), was also studied. The soil tillage was carried out longitudinally to the slope, according to the standard procedures for water erosion trials. In the BS treatment, the soil was permanently maintained bare and without surface crust through manual chiseling.

The experimental area was fertilized between 1988 and 2003 with $525 \mathrm{~kg} \mathrm{ha}^{-1}$ nitrogen (urea), 1,302 $\mathrm{kg} \mathrm{ha}^{-1}$ phosphorus $\left(\mathrm{P}_{2} \mathrm{O}_{5}\right)$, and $1,075 \mathrm{~kg} \mathrm{ha}^{-1}$ potassium $\left(\mathrm{K}_{2} \mathrm{O}\right)$, distributed to several crops. Soil acidity was corrected with limestone (PRNT $=85 \%, \mathrm{CaO}=42 \%$, and $\mathrm{MgO}=20 \%$ ), using $12 \mathrm{Mg} \mathrm{ha}^{-1}$ in October, 1988, and 3.5 Mg ha ${ }^{-1}$ of the same limestone in October, 1992. The BS treatment did not receive limestone or fertilizers.

During the first crop (soybean), $31 \mathrm{~kg} \mathrm{ha}^{-1}$ phosphorus $\left(\mathrm{P}_{2} \mathrm{O}_{5}\right)$ and $48 \mathrm{~kg} \mathrm{ha}^{-1}$ potassium $\left(\mathrm{K}_{2} \mathrm{O}\right)$ were applied to the soil; in the second crop (oats), $19 \mathrm{~kg} \mathrm{ha}^{-1}$ phosphorus $\left(\mathrm{P}_{2} \mathrm{O}_{5}\right)$ and $30 \mathrm{~kg} \mathrm{ha}^{-1}$ potassium $\left(\mathrm{K}_{2} \mathrm{O}\right)$ were applied. In the third crop (bean), $65 \mathrm{~kg} \mathrm{ha}^{-1}$ phosphorus $\left(\mathrm{P}_{2} \mathrm{O}_{5}\right)$ and $95 \mathrm{~kg} \mathrm{ha}^{-1}$ potassium $\left(\mathrm{K}_{2} \mathrm{O}\right)$ were added. For the fourth crop (vetch), no fertilizer was applied. In all crops, fertilizers were either broadcasted on the soil in no-tillage treatment, partially incorporated into the soil by minimum tillage, or completely incorporated by conventional soil tillage.

Sampling of surface runoff and measuring of soil and water losses followed methods proposed by Cogo (1978). The measured soil losses in the field were adjusted for the slope of $0.09 \mathrm{~m} \mathrm{~m}^{-1}$, considered the standard plot in the Universal Soil Loss Equation (USLE) (Wischmeier \& Smith, 1978).

Surface runoff samples produced by 51 erosive rain events were distributed as follows: 13 collected for the first crop, 17 for the second, 12 for the third, and 9 for the fourth crop. Selection of the surface runoff events for collecting samples was made as a function of the rainfall volume. The criterion for collecting surface runoff samples produced by each rainfall with volume higher than $20 \mathrm{~mm}$ was empirically adopted. Rainfall reached $1,936 \mathrm{~mm}$ during the experimental period, that was $73 \%$ of the total volume precipitated $(2,639 \mathrm{~mm})$, with the following relative distribution: $20 \%$ in the first crop, $36 \%$ in the second crop, $22 \%$ in the third crop, and $22 \%$ in the fourth crop.

After collection of surface runoff samples into the tanks for calculating soil and water losses (the results of soil and water losses, not presented here, can be seen in Bertol et al., 2004), surface runoff suspension of each tank (treatment) was sampled, in 0.3-L glass recipients. Immediately after the collection and after the settling of the 
sediment in the glass, a sample of the solution was removed for analysis of calcium and magnesium contents, as recommended by Tedesco et al. (1995). The remainder of the solution in the glass was stored in refrigerator $\left(4^{\circ} \mathrm{C}\right)$, for subsequent processing and chemical analysis of the other elements.

Samples of sediments collected in the surface runoff, produced by each erosive rain, were mixed together for each experimental plot and stored until the end of the plant growth cycle. In these samples, calcium, magnesium and organic carbon contents were determined, as recommended by Tedesco et al. (1995).

The total losses of calcium and magnesium in the surface runoff water were calculated by multiplying the concentration of the elements in water by the total loss of water. Total losses of calcium, magnesium and organic carbon in sediments were calculated by multiplying the concentration of the elements in sediments by the total loss of sediments.

Samples of the $0-0.025 \mathrm{~m}$ soil layer were collected at the end of the each crop cycle for analysis of calcium, magnesium and organic carbon. The analytical procedures for calcium, magnesium and organic carbon were the same used for sediments of the surface runoff, previously described. Simple linear regressions were calculated between calcium, magnesium and organic carbon concentrations in surface runoff sediments and their contents in the $0-0.025 \mathrm{~m}$ soil layer.

\section{RESULTS AND DISCUSSION}

\section{Calcium, magnesium and organic carbon concentra- tions in $\mathbf{0 - 0 . 0 2 5} \mathrm{m}$ soil layer}

Calcium contents in the $0-0.025 \mathrm{~m}$ soil layer reached high levels in the cropped systems, were similar among the different soil tillage systems, and were slightly greater than those found in the control, bare soil (Table 1). The magnesium concentration in this soil layer behaved similarly to calcium, with low contents, and correlated to the ordinary proportion of those two elements in the soil.

\section{Calcium and magnesium concentrations in surface runoff water}

Calcium and magnesium concentrations in surface runoff were relatively high in all treatments (Table 2), corroborating date of Schick (1999) and Schick et al. (2000). According to Dedecek et al. (1986) and Schick et al. (2000), this happens especially in limed and regularly fertilized soils. Liming the soil before setting up the trial contributed to the high concentrations of those elements in soil (Table 1) and, consequently, the surface runoff collected.

Calcium and magnesium concentrations in surface runoff under minimum soil tillage were, respectively, $48 \%$ and $44 \%$ greater than in the no-tillage, while under conventional soil tillage differences were respectively of $63 \%$ and $58 \%$, in the average of cropping cycles (Table

Table 1 - Calcium, magnesium and organic carbon concentrations in $0-0.025 \mathrm{~m}$ soil layer under different tillage systems along four crop cycles.

\begin{tabular}{|c|c|c|c|c|c|c|c|c|c|c|c|c|}
\hline \multirow{2}{*}{ Crop } & \multicolumn{2}{|c|}{ NT } & \multicolumn{2}{|c|}{ MT } & \multicolumn{2}{|c|}{$\mathrm{CT}$} & \multicolumn{2}{|c|}{$\mathrm{BS}$} & NT & MT & $\mathrm{CT}$ & $\mathrm{BS}$ \\
\hline & $\mathrm{Ca}$ & $\mathrm{Mg}$ & $\mathrm{Ca}$ & $\mathrm{Mg}$ & $\mathrm{Ca}$ & $\mathrm{Mg}$ & $\mathrm{Ca}$ & $\mathrm{Mg}$ & \multicolumn{4}{|c|}{ - } \\
\hline & \multicolumn{8}{|c|}{ - $\mathrm{mmol}_{\mathrm{c}} \mathrm{dm}^{-3}-\mathrm{c}^{-}$} & \multicolumn{4}{|c|}{ - } \\
\hline $1999 \mathrm{~S}$ & 52.8 & 41.5 & 72.3 & 31.9 & 73.5 & 41.8 & 67.6 & 41.2 & 87 & 89 & 88 & 60 \\
\hline $2000 \mathrm{~W}$ & 88.3 & 58.2 & 85.3 & 64.3 & 85.4 & 66.1 & 70.1 & 47.1 & 122 & 103 & 83 & 66 \\
\hline $2000 \mathrm{~S}$ & 73.1 & 35.9 & 63.2 & 29.1 & 62.5 & 38.2 & 56.4 & 39.1 & 84 & 75 & 66 & 51 \\
\hline $2001 \mathrm{~W}$ & 49.8 & 32.3 & 46.0 & 31.5 & 39.5 & 33.5 & 36.5 & 35.0 & 35 & 27 & 24 & 18 \\
\hline Mean & 66.0 & 42.0 & 66.7 & 39.2 & 65.2 & 44.9 & 57.7 & 40.6 & 82 & 74 & 65 & 49 \\
\hline
\end{tabular}

NT: no-tillage; MT: minimum soil tillage; CT: conventional soil tillage; BS: soil without crop; S: summer; W: Winter.

Table 2 - Calcium and magnesium concentrations in runoff water under different soil tillage systems along four crop cycles.

\begin{tabular}{|c|c|c|c|c|c|c|c|c|}
\hline \multirow{2}{*}{ Crop } & \multicolumn{2}{|c|}{ NT } & \multicolumn{2}{|c|}{ MT } & \multicolumn{2}{|c|}{ CT } & \multicolumn{2}{|c|}{ BS } \\
\hline & $\mathrm{Ca}$ & $\mathrm{Mg}$ & $\mathrm{Ca}$ & $\mathrm{Mg}$ & $\mathrm{Ca}$ & $\mathrm{Mg}$ & $\mathrm{Ca}$ & $\mathrm{Mg}$ \\
\hline & 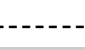 & $\ldots$ & $\ldots$ & 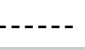 & $-\cdots$ & $\cdots$ & 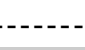 & - \\
\hline $1999 \mathrm{~S}$ & 31.4 & 28.8 & 61.3 & 44.6 & 65.5 & 50.8 & 42.1 & 39.3 \\
\hline $2000 \mathrm{~W}$ & 54.4 & 37.5 & 72.3 & 52.2 & 72.6 & 56.0 & 45.4 & 38.8 \\
\hline $2000 \mathrm{~S}$ & 25.2 & 25.7 & 48.3 & 39.3 & 59.2 & 48.1 & 41.7 & 40.6 \\
\hline $2001 \mathrm{~W}$ & 46.9 & 23.4 & 51.2 & 30.0 & 59.4 & 27.8 & 57.2 & 35.2 \\
\hline Mean & 39.5 & 28.9 & 58.3 & 41.5 & 64.2 & 45.7 & 46.6 & 38.5 \\
\hline
\end{tabular}

SNT: no-tillage; MT: minimum soil tillage; CT: conventional soil tillage; BS: soil without crop; S: summer; W: Winter. 
2). These results match those reported by Schick et al. (2000). An important factor that may have influenced the low calcium and magnesium concentrations in surface runoff under no-tillage was the fact that these elements, especially calcium, can complex with organic matter, which has neutral charge and is soluble, be leached with water down in the soil profile, and thus be reduced in the surface runoff in that soil tillage system. This phenomenon is favored under no-tillage because of greater accumulation of organic matter, and consequently, organic carbon in this soil, in comparison to conventional soil tillage (Table 1).

\section{Calcium, magnesium and organic carbon concentra- tions in surface runoff sediments}

Calcium and magnesium concentrations in surface runoff sediments were high in all treatments (Table 3 ), and greater than those usually found in surface runoff waters (Table 2). This is explained by the high contents of these elements in the limestone applied before setting up the experiment, and related to their concentrations in the superficial soil layer (Table 1). Moreover, calcium and magnesium can be easily transported adsorbed to sediments suspended in surface runoff. Reported results agree with those of Bertol (1994), Hernani et al. (1999), and Schick et al. (2000).

Calcium concentrations in surface runoff sediments were $27 \%$ and $10 \%$ lower in no-tillage than in minimum and conventional tillage systems, respectively (Table 3), with similar behavior as for the presence of this element in surface runoff (Table 2). Soil under minimum and conventional tillage systems was subjected to mechanical revolving, increasing decomposition of plant residues and lowering organic matter contents, with the consequent effect of decreasing cation exchange capacity of the soil solid phase. As a result, transport of calcium and magnesium in sediments of tilled soils was greater than in no-tillage system. Magnesium concentrations in surface runoff sediments were $42 \%$ lower under no-tillage than under minimum and conventional tillage systems also.
Organic carbon concentrations in surface runoff sediments were high in all treatments, bare soil included (Table 3). For cropped soil treatments, this can be explained by the contribution of plant residues, which were maintained in the soil surface in no-tillage, and partly and completely incorporated into the soil in minimum and conventional tillage, respectively. Tillage periodically added organic materials into the soil, hence maintaining their organic carbon content. This observation agrees with those of Schick et al. (2000), but differs from those of Owens et al. (2002), who registered greater concentrations of organic carbon in erosion sediments from cultivated areas. Regarding bare soil treatment, the relatively high concentration of organic carbon in surface runoff sediments can be related to the relatively high amount of native organic carbon still present in the soil (Table 1).

Organic carbon concentrations in surface runoff sediments were practically similar among soil cropping treatments (Table 3), that is, soil tillage systems did not influence this variable during the studied period. This result disagrees with those reported by Schick et al. (2000), who found higher concentrations of organic carbon under conservation soil tillage systems than in conventional soil tillage. However, Owens et al. (2002) found higher organic carbon concentrations in sediments from areas under conventional soil tillage than under conservation soil tillage systems. The organic carbon concentration in surface runoff sediments was on average $28 \%$ greater under tillage systems involving soil cropping (no-tillage, minimum tillage and conventional tillage) than for bare soil. This can be related to the organic carbon contents in the soil, since its concentration in the $0-0.025 \mathrm{~m}$ soil layer was $50 \%$ higher in these cropped soils than in bare soil (Table 1). Cropping adds organic residues to soils with subsequent influence on soil carbon input.

\section{Calcium and magnesium total losses in surface run- off water}

Calcium and magnesium total losses in surface runoff were high (Table 4), because these elements are relatively soluble in water and, due to their high contents

Table 3 - Calcium, magnesium and organic carbon concentrations in runoff sediments under different soil tillage systems along four crop cycles.

\begin{tabular}{|c|c|c|c|c|c|c|c|c|c|c|c|c|}
\hline \multirow{2}{*}{ Crop } & \multicolumn{2}{|c|}{ NT } & \multicolumn{2}{|c|}{ MT } & \multicolumn{2}{|c|}{$\mathrm{CT}$} & \multicolumn{2}{|c|}{$\mathrm{BS}$} & NT & MT & $\mathrm{CT}$ & $\mathrm{BS}$ \\
\hline & $\mathrm{Ca}$ & $\mathrm{Mg}$ & $\mathrm{Ca}$ & $\mathrm{Mg}$ & $\mathrm{Ca}$ & $\mathrm{Mg}$ & $\mathrm{Ca}$ & $\mathrm{Mg}$ & \multicolumn{4}{|c|}{ OC } \\
\hline & \multicolumn{8}{|c|}{ - } & \multicolumn{4}{|c|}{ - $\mathrm{g} \mathrm{kg}^{1}$} \\
\hline 1999S & 58.2 & 25.8 & 82.2 & 49.9 & 60.8 & 41.5 & 62.8 & 20.9 & 87 & 89 & 88 & 88 \\
\hline $2000 \mathrm{~W}$ & 46.4 & 26.6 & 74.5 & 54.1 & 50.0 & 47.6 & 61.1 & 25.5 & 109 & 91 & 110 & 80 \\
\hline $2000 \mathrm{~S}$ & 60.8 & 26.4 & 88.7 & 44.7 & 71.4 & 40.5 & 63.9 & 18.1 & 119 & 118 & 131 & 85 \\
\hline $2001 \mathrm{~W}$ & 51.5 & 35.0 & 53.2 & 42.1 & 57.2 & 37.2 & 33.5 & 17.0 & 53 & 39 & 44 & 26 \\
\hline Mean & 54.2 & 28.5 & 74.7 & 47.7 & 59.9 & 41.7 & 55.3 & 20.4 & 92 & 84 & 93 & 70 \\
\hline
\end{tabular}

NT: no-tillage; MT: minimum soil tillage; CT: conventional soil tillage; BS: soil without crop; S: summer; W: Winter.

Sci. Agric. (Piracicaba, Braz.), v.62, n.6, p.578-584, Nov./Dec. 2005 
in soil (Table 1), which was limed and regularly fertilized.

Total calcium losses were higher under conventional soil tillage with crop (CT) and in bare soil (BS), being, on average about $32 \%$ higher than the average for the conservation soil tillage systems (no-tillage and minimum tillage) (Table 4). This can be explained by the fact that the volume of water lost was substantially greater under conventional soil tillage systems (CT and BS), similarly to a parallel study on the same experimental area (Bertol et al., 2004). High calcium concentration in surface runoff under conventional soil tillage with cultivation (CT) (NT and MT - Table 2) was also reported by Hernani et al. (1999), Schick et al. (2000) and Cassol et al. (2002). When no-tillage and conventional tillage systems were compared, calcium losses under no-tillage was equivalent to $32 \%$ of that from conventional tillage, showing that soil tillage effectively reduces $\mathrm{Ca}$ losses.

The quantities of magnesium lost in surface runoff were similar to those of calcium, and match results of Hernani et al. (1999) and Schick et al. (2000). In notillage system, losses of magnesium in surface runoff water were $31 \%$ of those occurring under conventional tillage with cultivation (CT), possibly because the lower volume of water loss, since the concentrations of this element in surface runoff were similar in both treatments.

\section{Calcium, magnesium and organic carbon total losses in surface runoff sediments}

Calcium and magnesium total losses in surface runoff sediments (Table 5) were proportional to the amounts of soil lost, as measured by Bertol et al. (2004) in a study developed on the same experimental site, during the same period time. This is explained by the fact that those elements are found in high concentrations in soil (Table 3) and are less susceptible to leaching loss in water.

Calcium and magnesium total losses in surface runoff sediments were high under conventional tillage with crop (CT) and in bare soil (BS), being respectively 36 and 2 times greater than the mean of conservation soil tillage systems (NT and MT) (Table 5). This was mainly due to the greater soil losses that happened under conventional tillage in relation to conservation soil tillage systems, since calcium and magnesium concentrations in surface runoff sediments under conventional tillage were, on average, only slightly lower than those under conservation soil tillage (Table 3 ).

The total amount of organic carbon lost in surface runoff sediments were in general high (Table 5), due to high contents of organic matter in this soil (Table 1). Organic matter is one of the first particles of the soil removed by water erosion, because not only its high concentration in soil surface but also for its low density (Barrows \& Kilmer, 1963). Organic carbon was lost in high

Table 4 - Calcium and magnesium total losses in runoff water under different soil tillage systems along four crop cycles.

\begin{tabular}{|c|c|c|c|c|c|c|c|c|}
\hline \multirow{2}{*}{ Crop } & \multicolumn{2}{|c|}{ NT } & \multicolumn{2}{|c|}{ MT } & \multicolumn{2}{|c|}{$\mathrm{CT}$} & \multicolumn{2}{|c|}{ BS } \\
\hline & $\mathrm{Ca}$ & $\mathrm{Mg}$ & $\mathrm{Ca}$ & $\mathrm{Mg}$ & $\mathrm{Ca}$ & $\mathrm{Mg}$ & $\mathrm{Ca}$ & $\mathrm{Mg}$ \\
\hline & -.-.- & $\cdots$ & $\ldots$ & $\cdots$ & $\cdots$ & $\cdots$ & $\cdots$ & --.-- \\
\hline 1999S & 0.12 & 0.11 & 0.55 & 0.40 & 0.98 & 076 & 1.74 & 1.60 \\
\hline $2000 \mathrm{~W}$ & 1.54 & 1.06 & 1.86 & 1.34 & 3.88 & 3.00 & 1.88 & 1.61 \\
\hline $2000 \mathrm{~S}$ & 0.15 & 0.16 & 0.97 & 0.79 & 3.45 & 2.80 & 3.82 & 3.72 \\
\hline $2001 \mathrm{~W}$ & 5.40 & 2.70 & 7.34 & 4.30 & 14.14 & 6.62 & 11.47 & 7.06 \\
\hline Mean & 1.80 & 1.01 & 2.68 & 1.71 & 5.68 & 3.30 & 4.73 & 3.50 \\
\hline
\end{tabular}

NT: no-tillage; MT: minimum soil tillage; CT: conventional soil tillage; BS: soil without crop; S: summer; W: Winter.

Table 5 - Calcium, magnesium and organic carbon total losses in runoff sediments under different soil tillage systems along four crop cycles.

\begin{tabular}{|c|c|c|c|c|c|c|c|c|c|c|c|c|}
\hline \multirow{2}{*}{ Crop } & \multicolumn{3}{|c|}{ NT } & \multicolumn{3}{|c|}{ MT } & \multicolumn{3}{|c|}{ CT } & \multicolumn{3}{|c|}{$\mathrm{BS}$} \\
\hline & $\mathrm{Ca}$ & $\mathrm{Mg}$ & $\mathrm{OC}$ & $\mathrm{Ca}$ & $\mathrm{Mg}$ & $\mathrm{OC}$ & $\mathrm{Ca}$ & $\mathrm{Mg}$ & $\mathrm{OC}$ & $\mathrm{Ca}$ & $\mathrm{Mg}$ & $\mathrm{OC}$ \\
\hline & 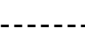 & $\cdots$ & $\cdots$ & $\cdots$ & - & $\ldots$ & $\cdots$ & & & & & --- \\
\hline $1999 \mathrm{~S}$ & 0.03 & 0.01 & 3 & 0.08 & 0.03 & 4 & 0.13 & 0.05 & 10 & 13.74 & 2.74 & 963 \\
\hline $2000 \mathrm{~W}$ & 0.30 & 0.10 & 35 & 1.55 & 0.68 & 95 & 3.98 & 2.27 & 438 & 69.47 & 17.40 & 4,548 \\
\hline $2000 \mathrm{~S}$ & 0.08 & 0.02 & 8 & 0.41 & 0.12 & 27 & 1.34 & 0.46 & 123 & 20.15 & 3.43 & 1,340 \\
\hline $2001 \mathrm{~W}$ & 0.38 & 0.15 & 19 & 0.43 & 0.20 & 16 & 1.67 & 0.65 & 36 & 6.77 & 2.06 & 263 \\
\hline Mean & 0.20 & 0.07 & 16 & 0.62 & 0.26 & 36 & 1.78 & 0.86 & 152 & 27.53 & 6.41 & 1,779 \\
\hline
\end{tabular}

NT: no-tillage; MT: minimum soil tillage; CT: conventional soil tillage; BS: soil without crop; S: summer; W: Winter.

Sci. Agric. (Piracicaba, Braz.), v.62, n.6, p.578-584, Nov./Dec. 2005 
amounts in all treatments, but in higher amounts in soil without cultivation, as a result of the total soil losses (Bertol et al., 2004). Protection of the soil surface by plants residue is one of the most effective conservation
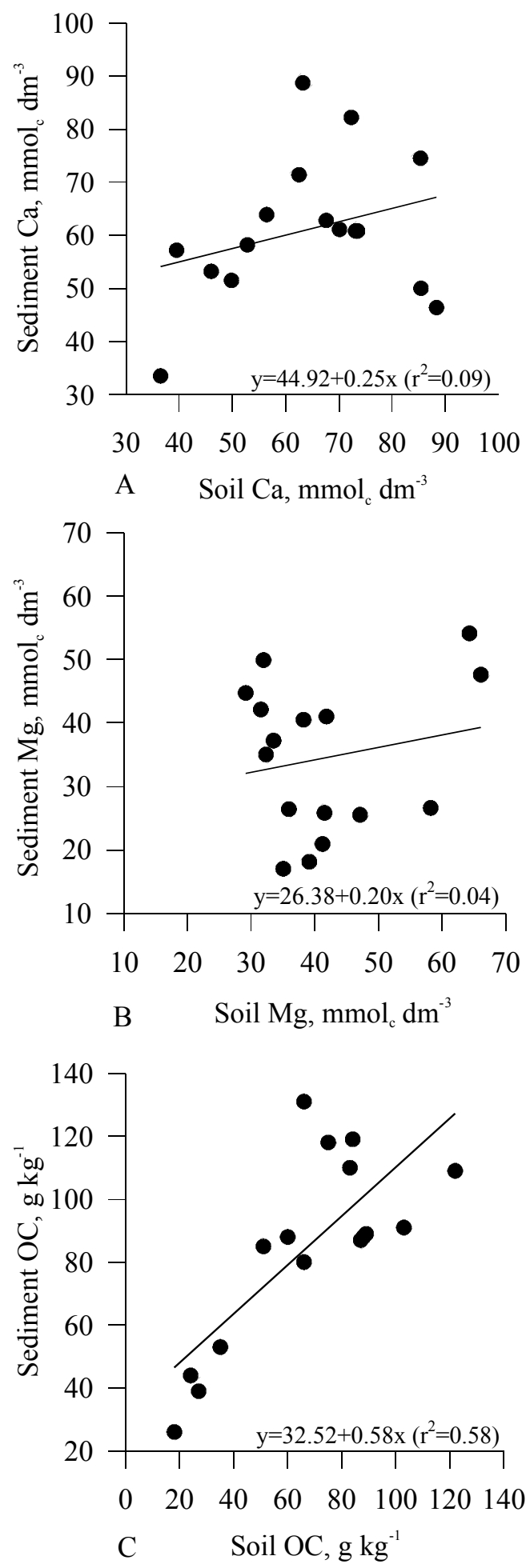

Figure 1 - Linear regression between (a) $\mathrm{Ca}$ in $0-0.025 \mathrm{~m}$ soil layer and sediment in the runoff, (b) $\mathrm{Mg}$ in $0-0.025 \mathrm{~m}$ soil layer and sediment in the runoff, and (c) OC in 0 $0.025 \mathrm{~m}$ soil layer and sediment in the runoff, on diffetents soil tillage systems during four crops practices of agricultural soils, since no-tillage and minimum tillage with low mechanical mobilization is an effective method to reduce soil losses, hence decreasing organic carbon losses. In the no-tillage and minimum tillage systems, organic carbon contents in surface runoff sediments was reduced by $83 \%$ in average, in relation to conventional tillage.

Correlation between calcium, magnesium and organic carbon in soil and in sediment of the surface runoff

Calcium and magnesium concentrations in sediments of the surface runoff did not correlate well with contents of these elements in the $0-0.025 \mathrm{~m}$ soil layer (Figure $1, \mathrm{~A}$ and B). This result differs from correlations obtained by Schick et al. (2000), on the same experiment that found significant correlation. Therefore, in the case of these elements, it was not possible to predict the concentrations in surface runoff sediments, by knowing only their contents in the superficial soil layer. Factors that influenced calcium and magnesium concentrations in the superficial soil layer and in sediments of the surface runoff may have varied in different ways, without a clear tendency. Therefore, it can be recommended such correlations to be made over data collected over a long-term period of time.

In the case of organic carbon, its concentration in $0-0.025 \mathrm{~m}$ soil layer explained $58 \%$ of the concentration of surface runoff sediments (Figure 1, C), agreeing with Schick et al. (2000). In other words, as opposed to the concentrations of calcium and magnesium, organic carbon contents in superficial soil layer can be used to predict its concentration in surface runoff sediments, considering the significance of the correlation coefficient of the linear equation used to describe the relationship.

\section{REFERENCES}

BARROWS, H.L.; KILMER, V.J. Plant nutrient losses from soil by water erosion. In: NORMANN, A.G. Advances in Agronomy, v.15, p.303$316,1963$.

BERTOL, I. Perdas de nutrientes por erosão hídrica em diferentes sistemas de manejo de solo sob rotação de culturas. Universidade \& Desenvolvimento, v.2, p.174-184, 1994.

BERTOL, I. Comprimento crítico de declive para preparos conservacionistas de solo. Porto Alegre: UFRGS, 1995. 185p. (Tese - Doutorado)

BERTOL, I.B.; MELLO, E.L.; GUADAGNIN, J.C.; ZAPAROLLI, A.L.V.; CARRAFA, M.R. Nutrient losses by water erosion. Scientia Agricola, v.60, p.581-586, 2003.

BERTOL, I.; GUADAGNIN, J.C.; CASSOL, P.C.; AMARAL, A.J.; BARBOSA, F.T. Perdas de P e K por erosão hídrica em um Inceptisol sob chuva natural. Revista Brasileira de Ciência do Solo, v.28, p.485494, 2004.

CASSOL, E.A.; LEVIEN, R.; ANGHINONI, I.; BADELUCCI, M.P. Perdas de nutrientes por erosão em diferentes métodos de melhoramento de pastagem nativa no Rio Grande do Sul. Revista Brasileira de Ciência do Solo, v.26, p.705-712, 2002.

COGO, N.P. Uma contribuição à metodologia de estudo das perdas por erosão em condições de chuva natural. I. Sugestões gerais, medição do volume, amostragem e quantificação da enxurrada superficial $\left(1^{\mathrm{a}}\right.$ aproximação). In: ENCONTRO NACIONAL DE PESQUISA SOBRE CONSERVAÇÃO DO SOLO, 2., Passo Fundo, 1978. Anais... Passo Fundo: EMBRAPA, CNPT, 1978. p.75-98. 
COGO, N.P. Effect of residue cover, tillage induced roughness, and slope length on erosion and related parameters. West Lafayette: Purdue University, 1981. 346p. (Tese - Doutorado)

DEDECEK, R.A.; RESCK, D.V.S.; FREITAS JR., E. Perdas de solo, água e nutrientes por erosão em Latossolo Vermelho escuro nos cerrados em diferentes cultivos sob chuva natural. Revista Brasileira de Ciência do Solo, v.10, p.265-272, 1986.

ELTZ, F.L.F.; PEIXOTO, R.T.G.; JASTER, F. Efeitos de sistemas de preparo do solo nas propriedades físicas e químicas de um Latossolo Bruno álico. Revista Brasileira de Ciência do Solo, v.13, p.259-267, 1989.

FAVARETTO, N. Gypsum amendment and exchangeable calcium and magnesium related to water quality and plant nutrition. West Lafayette: Purdue University, 2002. 150p. (Tese - Doutorado)

GUADAGNIN, J.C. Perdas de nutrientes e carbono orgânico pela erosão hídrica, em um Cambissolo Húmico alumínico léptico submetido a diferentes sistemas de preparo e cultivo do solo. Lages: UDESC, 2003. 142p. (Dissertação - Mestrado)

HERNANI, L.C.; KURIHARA, C.H.; SILVA, W.M. Sistemas de manejo do solo e perdas de nutrientes e matéria orgânica por erosão. Revista Brasileira de Ciência do Solo, v.23, p.145-154, 1999.

OWENS, L.B.; MALONE, R.W.; HOTHEM D.L.; STARR, G.C.; LAL, R. Sediment carbon concentration and transport from small watersheds under various conservation tillage practices. Soil \& Tillage Research, v.67, p.65-73, 2002.
POTE, D.H.; DANIEL, T.C.; SHARPLEY, A.N.; MOORE JUNIOR, P.A.; EDWARDS, D.R.; NICHOLS, D.J. Relating extractable soil phosphorus to phosphorus losses in runoff. Soil Science Society of America Journal, v.60, p.855-859, 1996.

SCHICK, J. Erosão hídrica em Cambissolo Húmico álico submetido a diferentes sistemas de preparo e cultivo do solo. Lages: UDESC, 1999. 114p. (Dissertação - Mestrado)

SCHICK, J.; BERTOL, I.; BALBINOT JR., A.A.; BATISTELA, O. Erosão hídrica em Cambissolo Húmico alumínico submetido a diferentes sistemas de preparo e cultivo do solo: II. Perdas de nutrientes e carbono orgânico. Revista Brasileira de Ciência do Solo, v.24, p.437-447, 2000.

STOLTENBERG, N.L.; WHITE, J.L. Selective loss of plant nutrients by erosion. Soil Science Society of America Proceedings, v.17, p.406$410,1953$.

TEDESCO, M.J.; VOLKWEISS, S.J.; BOHNEN, H. Análise de solos, plantas e outros materiais. 2.ed. Porto Alegre: UFRGS, 1995. 174p.

WISCHMEIER, W.H.; SMITH D.D. Predicting rainfall erosion losses: the guide to conservation planning. Washington: USDA, 1978. 58p. (Agricultural Handbook, 537)

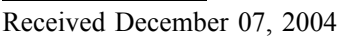

Accepted October 10, 2005 